\title{
Geological investigation and monitoring of Ramhlun Sports Complex landslide, Aizawl, India
}

\author{
Laldinpuia \\ Department of Geology, Pachhunga University College, Aizawl 796001, India
}

\begin{abstract}
Ramhlun Sports Complex is situated at the eastern limb of Aizawl anticline, Mizoram. Landslide took place in August 2012 which badly affected 16 houses. Due to presence of tension cracks, 38 houses are vacated within a safe time, but dismantled and 10 buildings are collapsed in August 2013. This affected 195 persons of 41 families. A geological investigation was performed; representative soil samples are analyzed as Atterberg's limits, CBR (California bearing ratio), OMC (optimum moisture content) and MDD (maximum dry density), respectively. Instrumentations and monitoring of the movement using crackmeter and tape extensometer also done for two years. The CBR and MDD values are too low as compared to the safety standards, while moisture content is too high. This may show that the movement and erosion rate may be high. The movement was relatively high when rainfall increases. It was observed that, the area is not suitable and unsafe for settlement; constructions of road/ pavement are not recommended.
\end{abstract}

Received 8 July 2019 Accepted 26 September 2019

*For correspondence: dinpuiageo@gmail.com

Contact us: sciencevision@outlook.com

Keywords: Atterberg's limits; California bearing ratio; crackmeter; extensometer; optimum moisture content; maximum dry density.

\section{Introduction}

Aizawl city is one of the most landslide prone cities in the country. The landslide mostly occurred on the months of May, June and October. These landslides cause loss of human life, properties, and disruption of communication networks. ${ }^{1}$ Ramhlun Sports Complex is within Ramhlun Local Council which is administratively under Ward III of Aizawl Municipal Council (AMC). Tension cracks was first observed on 19 July 2004 and prominent cracks reported on 14 September 2007. About 40 families are affected by these cracks and landslides during 10 -20 August 2012. 16 houses are dismantled and collapsed on August 2013 after landslide.

The state government had reported and asked a supported to National Disaster Management Authority (NDMA), New Delhi, and Geological Survey of India (GSI), Shillong, about the catastrophic disaster. Joint geotechnical investigations and mitigations were taken up by GSI and the geologists at the Mizoram Geology \& Mineral Resources Directorate (DGMR), financially supported by National Disaster Management Authority (NDMA), Government of India, for the first time in the country under National Landslide Risk Mitigation Project. ${ }^{2}$

Ramhlun Sports Complex mass landslide covered more than $7000 \mathrm{sq} \mathrm{m}$ and the area coordinates between N23 $44^{\prime} 38.50^{\prime \prime}-E 92^{\circ} 43^{\prime} 42.18^{\prime \prime}$ and $\mathrm{N} 23^{\circ} 44^{\prime} 39.31^{\prime \prime}-\mathrm{Eg}^{\circ} 43^{\prime} 36.70^{\prime \prime}$ (Figure 1). The present study was performed in the selected geotechnical parameters which are not done by GSI and DGMR, investigated for linking road which is a part of mitigation measures as drafted and instrumentation and monitoring of this mass movement. 


\section{Methodology}

\section{Geotechnical Investigations}

1) Atterberg limits ${ }^{3}$ :

(i) Liquid limit: Soil sample passing through a 425 $\mu \mathrm{m}$ sieve, weighing $200 \mathrm{~g}$ was mixed with water to form a thin homogenous paste. The paste was collected inside the Casagrande's apparatus cup with a groove created and the number of blows to close it was recorded Also, moisture contents were determined for the respective sample tested for liquid limit.

(ii) Plastic limit: About $15 \mathrm{~g}$ of soil, passing through a No. 40 sieve, was mixed thoroughly. The soil was rolled on a glass plate with the hand until it was about $3.2 \mathrm{~mm}$ in diameter. This procedure of mixing and rolling was repeated till the soil thread breaks apart. The water content of the crumbled portion of the thread was determined.
2) The CBR test is a widely accepted measure of strength of subgrade soils for construction of pavement. The strength of soil can be considered to be indexed by its CBR values. ${ }^{4-6}$ The test consists of causing a plunger of standard are to penetrate a soil sample. The force (load) required to cause the penetration was plotted against measured penetration, the readings noted at regular intervals. This information was plotted on standard graph and the plot of the test will establish the CBR result of the tested soil. The sub grades generally wet up to a greater extent than bases and sub-bases. ${ }^{7-9}$

3) MDD \& OMC ${ }^{10}$ : A 5-kg sample of air-dried soil passing through the $19 \mathrm{~mm}$ IS sieve was thoroughly mixed with $3-5 \%$ of water was prepared, mould was used for determination of MDD and OMC as per IS procedure.

\section{Monitoring}

1) Field work: A Brunton compass will employ in

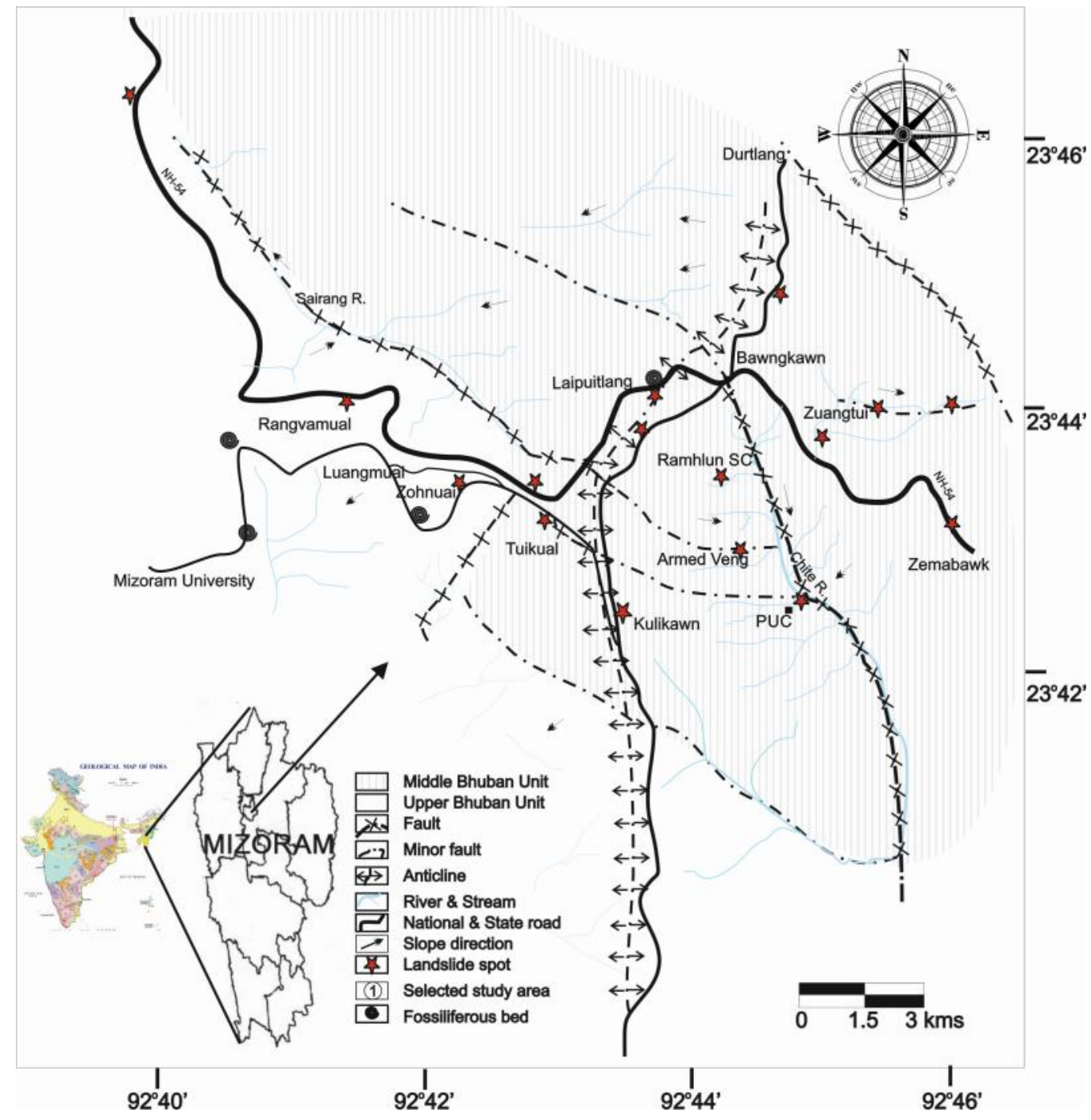

Figure 1 | Geological/location map of Ramhlun Sports Complex (Ramhlun SC) showing landslide spots, Aizawl. ${ }^{1}$ 



Figure 2 | Displacement of crack using crackmeter instrument (SIS 102 \& 101).
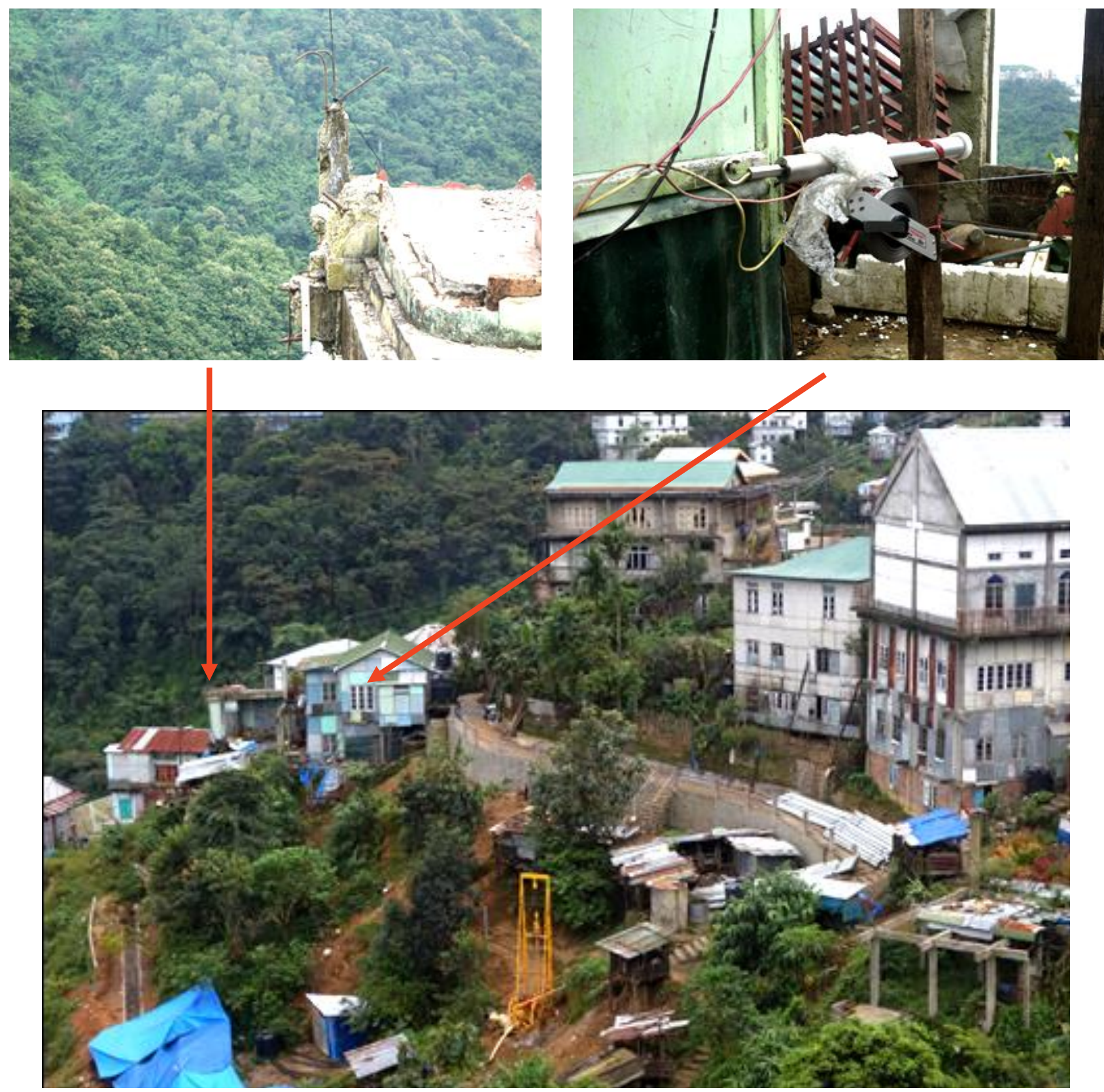

Figure 3 | Monitoring the movement using tape extensometer (SIS 400). 

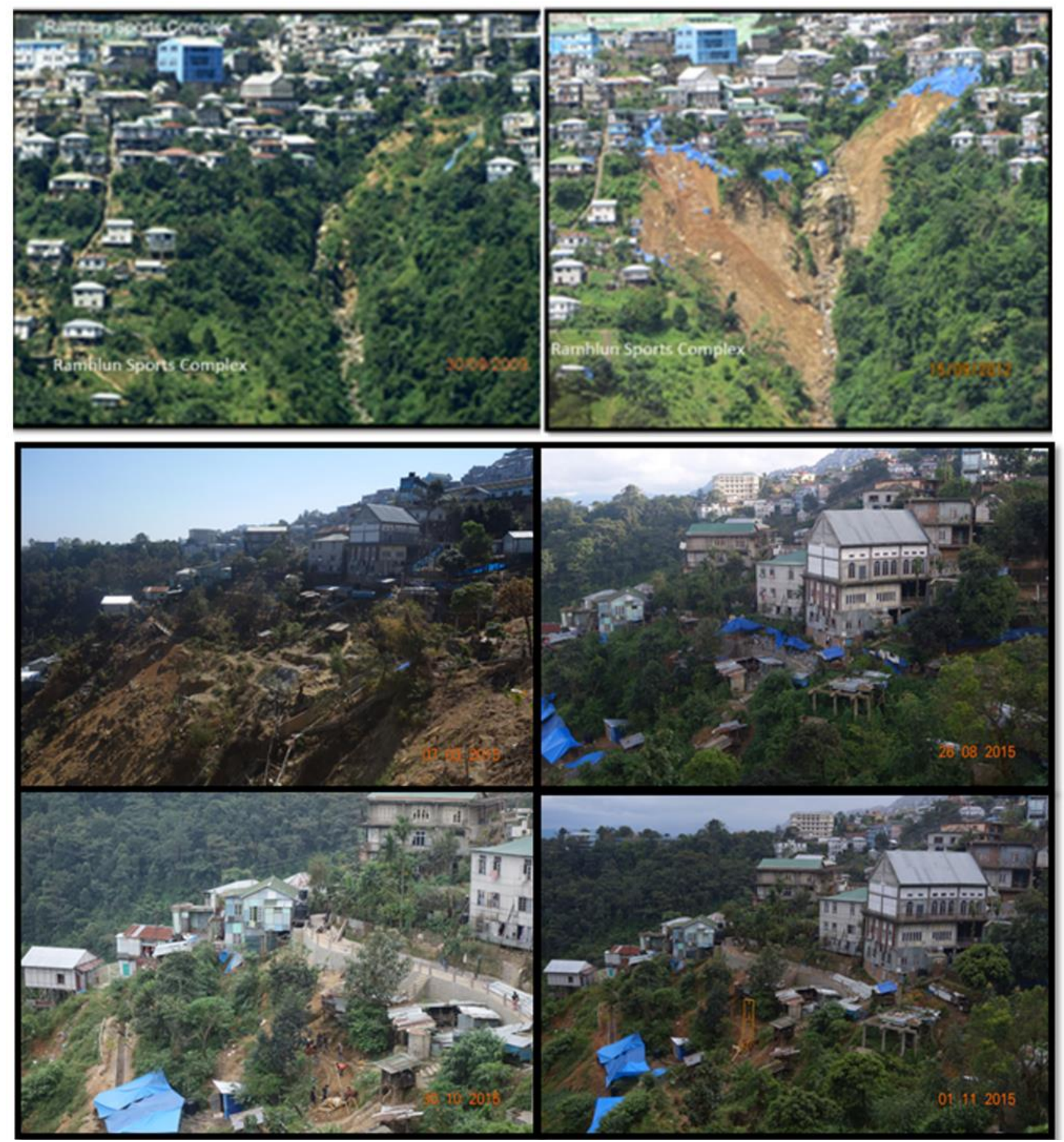

Figure 4 | Photographic monitoring of the study area. 
Table 1 | Observation values of liquid limit and plastic limit.

\begin{tabular}{cccccccc}
\hline $\begin{array}{c}\text { Sample } \\
\text { No }\end{array}$ & $\begin{array}{c}\text { No of } \\
\text { Blows }\end{array}$ & $\begin{array}{c}\text { Wt of } \\
\text { Contr }\end{array}$ & $\begin{array}{c}\text { LIQUID LIMIT (LL) SHEET } \\
\text { Cont }+\end{array}$ & $\begin{array}{c}\text { Contr }+ \\
\text { wry soil }\end{array}$ & $\begin{array}{c}\text { Wt of } \\
\text { dry soil }\end{array}$ & $\begin{array}{c}\text { Wt of } \\
\text { water }\end{array}$ & $\begin{array}{c}\text { Moisture } \\
\%\end{array}$ \\
\hline 1 & 17 & 20.77 & 31.17 & 29.95 & 9.18 & 1.22 & 13.29 \\
\hline 2 & 23 & 2.55 & 35.77 & 30.15 & 27.6 & 5.62 & 20.36 \\
\hline 3 & 27 & 22.25 & 34.57 & 31.71 & 9.46 & 2.86 & 30.23 \\
\hline 4 & 32 & 22.08 & 30.32 & 28.19 & 6.11 & 2.13 & 34.86 \\
\hline & & & PLASTIC LIMIT (PL) SHEET & & & \\
\hline 5 & & 22.17 & 24.07 & 23.75 & 1.58 & 0.32 & 20.25 \\
\hline 7 & 21.19 & 25.81 & 24.98 & 3.79 & 0.83 & 21.9 \\
\hline
\end{tabular}

Table 2 | Results of CBR, MDD \& OMC.

\begin{tabular}{|c|c|c|c|c|}
\hline \multirow{2}{*}{$\begin{array}{c}\text { Sample } \\
\text { No. }\end{array}$} & \multicolumn{2}{|c|}{ CBR Value } & \multirow{2}{*}{$\begin{array}{c}\text { MDD } \\
\text { in } \mathrm{g} / \mathrm{cc}\end{array}$} & \multirow{2}{*}{$\begin{array}{l}\text { OMC } \\
\text { in \% }\end{array}$} \\
\hline & $2.50 \mathrm{~mm}$ & $5.00 \mathrm{~mm}$ & & \\
\hline RSC-I & $6.95 \%$ & & 1752 & 15.70 \\
\hline RS & & & 1 & 0.4 \\
\hline RSC- & $5.07 \%$ & 5.56 & 1.745 & 18.60 \\
\hline RSC-IV & $5.56 \%$ & $5.79 \%$ & 1.726 & 15.90 \\
\hline
\end{tabular}

Table 3 | Monitoring using tape extensometer \& crackmeter with rainfall data.

\begin{tabular}{|c|c|c|c|c|c|}
\hline Date & Location & Instrument & Initial & Final & Rainfall \\
\hline 03.07 .15 & $\begin{array}{l}\text { N234ㄴ'37.93" } \\
\text { E92 } 43^{\prime} 39.27^{\prime \prime}\end{array}$ & Tape Extensometer & $0.00 \mathrm{~mm}$ & $0.00 \mathrm{~mm}$ & $3.0 \mathrm{~mm}$ \\
\hline 10.07.15 & -do- & -do- & $0.00 \mathrm{~mm}$ & $0.02 \mathrm{~mm}$ & $8.5 \mathrm{~mm}$ \\
\hline 17.07 .15 & $\begin{array}{l}\text { N234'ㄱ'37.93" } \\
\text { E92 } 43^{\prime} 39.27^{\prime \prime}\end{array}$ & Tape Extensometer & $0.00 \mathrm{~mm}$ & $0.00 \mathrm{~mm}$ & $6.0 \mathrm{~mm}$ \\
\hline 24.07 .15 & -do- & -do- & $0.00 \mathrm{~mm}$ & $0.00 \mathrm{~mm}$ & $6.5 \mathrm{~mm}$ \\
\hline 31.07 .15 & $\begin{array}{l}\text { N234ㄴ'37.93" } \\
\text { E92 }^{\circ} 43^{\prime} 39.27^{\prime \prime}\end{array}$ & Tape Extensometer & $0.00 \mathrm{~mm}$ & $0.00 \mathrm{~mm}$ & $2.6 \mathrm{~mm}$ \\
\hline 07.08 .15 & -do- & - do- & $0.00 \mathrm{~mm}$ & $0.01 \mathrm{~mm}$ & $39.7 \mathrm{~mm}$ \\
\hline 14.08.15 & $\begin{array}{l}\text { N234ㄴ'37.93" } \\
\text { E92 }^{\circ} 43^{\prime} 39.27^{\prime \prime}\end{array}$ & Tape Extensometer & $0.00 \mathrm{~mm}$ & $0.00 \mathrm{~mm}$ & $2.1 \mathrm{~mm}$ \\
\hline 21.08 .15 & - do- & -do- & $0.00 \mathrm{~mm}$ & $0.00 \mathrm{~mm}$ & $0.7 \mathrm{~mm}$ \\
\hline 27.08 .15 & $\begin{array}{l}\text { N234ㄴ'37.93" } \\
\text { E92 }^{\circ} 43^{\prime} 39.27^{\prime \prime}\end{array}$ & Tape Extensometer & $0.00 \mathrm{~mm}$ & $0.05 \mathrm{~mm}$ & $90.3 \mathrm{~mm}$ \\
\hline 04.09 .15 & - do- & - do- & $0.00 \mathrm{~mm}$ & $0.00 \mathrm{~mm}$ & $1.5 \mathrm{~mm}$ \\
\hline 11.09 .15 & $\begin{array}{l}\text { N234ㄴ'37.93" } \\
\text { E92 } 43^{\circ} 39.27^{\prime \prime}\end{array}$ & Tape Extensometer & $0.00 \mathrm{~mm}$ & $0.00 \mathrm{~mm}$ & $0.0 \mathrm{~mm}$ \\
\hline 18.09 .15 & - do- & - do- & $0.00 \mathrm{~mm}$ & $0.00 \mathrm{~mm}$ & $0.0 \mathrm{~mm}$ \\
\hline 25.09 .15 & $\begin{array}{l}\text { N23ํ4'37.93" } \\
\text { E92 }^{\circ} 43^{\prime} 39.27^{\prime \prime}\end{array}$ & Tape Extensometer & $0.00 \mathrm{~mm}$ & $0.00 \mathrm{~mm}$ & $12.2 \mathrm{~mm}$ \\
\hline 02.10 .15 & -do- & -do- & $0.00 \mathrm{~mm}$ & $0.00 \mathrm{~mm}$ & $36.2 \mathrm{~mm}$ \\
\hline 09.10 .15 & $\begin{array}{l}\text { N234'ㄱ'37.93" } \\
\text { E92 } 43^{\prime} 39.27^{\prime \prime}\end{array}$ & Tape Extensometer & $0.00 \mathrm{~mm}$ & $0.03 \mathrm{~mm}$ & $32.4 \mathrm{~mm}$ \\
\hline 16.10 .15 & - do- & - do- & $0.00 \mathrm{~mm}$ & $0.00 \mathrm{~mm}$ & $3.4 \mathrm{~mm}$ \\
\hline 23.10 .15 & $\begin{array}{l}\text { N234'ㄱ‥93" } \\
\text { E92 } 43^{\circ} 39.27^{\prime \prime}\end{array}$ & Tape Extensometer & $0.00 \mathrm{~mm}$ & $0.00 \mathrm{~mm}$ & $0.0 \mathrm{~mm}$ \\
\hline 30.10 .15 & $\begin{array}{l}\text { N234ㄴ'37.93" } \\
\text { E92 } 43^{\prime} 39.27^{\prime \prime}\end{array}$ & - do- & $0.00 \mathrm{~mm}$ & $0.00 \mathrm{~mm}$ & $0.0 \mathrm{~mm}$ \\
\hline
\end{tabular}




\begin{tabular}{|c|c|c|c|c|c|}
\hline 01.11 .15 & -do- & Tape Extensometer & $0.00 \mathrm{~mm}$ & $0.00 \mathrm{~mm}$ & $2.2 \mathrm{~mm}$ \\
\hline 05.06 .16 & $\begin{array}{l}\text { N234'37.93" } \\
\text { E92 } 43^{\circ} 39.27^{\prime \prime}\end{array}$ & -do- & $0.00 \mathrm{~mm}$ & $0.02 \mathrm{~mm}$ & $73.5 \mathrm{~mm}$ \\
\hline 12.06 .16 & -do- & Tape Extensometer & $0.00 \mathrm{~mm}$ & $0.00 \mathrm{~mm}$ & $0.0 \mathrm{~mm}$ \\
\hline 19.06.16 & $\begin{array}{l}\text { N234'37.93" } \\
\text { E92 }^{\circ} 43^{\prime} 39.27^{\prime \prime}\end{array}$ & -do- & $0.00 \mathrm{~mm}$ & $0.00 \mathrm{~mm}$ & $0.0 \mathrm{~mm}$ \\
\hline 26.06 .16 & -do- & Tape Extensometer & $0.00 \mathrm{~mm}$ & $0.00 \mathrm{~mm}$ & $8.0 \mathrm{~mm}$ \\
\hline 03.07.16 & $\begin{array}{l}\text { N234ㄴ'37.93" } \\
\text { E92 } 43^{\circ} 39.27^{\prime \prime}\end{array}$ & -do- & $0.00 \mathrm{~mm}$ & $0.00 \mathrm{~mm}$ & $3.2 \mathrm{~mm}$ \\
\hline 10.07.16 & -do- & Tape Extensometer & $0.00 \mathrm{~mm}$ & $0.00 \mathrm{~mm}$ & $18.5 \mathrm{~mm}$ \\
\hline 17.07.16 & 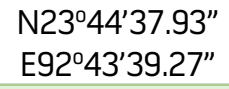 & - do- & $0.00 \mathrm{~mm}$ & $0.00 \mathrm{~mm}$ & $5.6 \mathrm{~mm}$ \\
\hline 24.07 .16 & - do- & Tape Extensometer & $0.00 \mathrm{~mm}$ & $0.00 \mathrm{~mm}$ & $1.1 \mathrm{~mm}$ \\
\hline 31.07 .16 & $\begin{array}{l}\text { N23ํ4'37.93" } \\
\text { E92 }^{\circ} 43^{\prime} 39.27^{\prime \prime}\end{array}$ & -do- & $0.00 \mathrm{~mm}$ & $0.00 \mathrm{~mm}$ & $34.8 \mathrm{~mm}$ \\
\hline 07.08 .16 & -do- & Tape Extensometer & $0.00 \mathrm{~mm}$ & $0.00 \mathrm{~mm}$ & $0.0 \mathrm{~mm}$ \\
\hline 14.08.16 & $\begin{array}{l}\text { N234ㄴ'37.93" } \\
\text { E92 } 43^{\circ} 39.27^{\prime \prime}\end{array}$ & Tape Extensometer & $0.00 \mathrm{~mm}$ & $0.04 \mathrm{~mm}$ & $95.1 \mathrm{~mm}$ \\
\hline 02.10 .15 & $\begin{array}{l}\text { N234ㄴ'38.13" } \\
\text { E92 }^{\circ} 43^{\prime} 37.36^{\prime \prime}\end{array}$ & Crackmeter & 0.00 & ERROR & $36.2 \mathrm{~mm}$ \\
\hline 09.10 .15 & -do- & -do- & & ERROR & $32.4 \mathrm{~mm}$ \\
\hline 16.10 .15 & $\begin{array}{l}\text { N23ํ4'38.13" } \\
\text { E92 }^{\circ} 43^{\prime} 37.36^{\prime \prime}\end{array}$ & Crackmeter & 0.000 & 0.000 & $3.4 \mathrm{~mm}$ \\
\hline 23.10 .15 & - do- & -do- & 0.000 & 0.000 & $0.0 \mathrm{~mm}$ \\
\hline 01.11 .15 & $\begin{array}{l}\text { N23ㄴ4'38.13" } \\
\text { E92 } 43^{\prime} 37.36^{\prime \prime}\end{array}$ & Crackmeter & & ERROR & $2.2 \mathrm{~mm}$ \\
\hline 05.06 .16 & - do- & - do- & 0.000 & 0.003 & $73.5 \mathrm{~mm}$ \\
\hline 12.06.16 & $\begin{array}{l}\mathrm{N} 23^{\circ} 44^{\prime} 38.13^{\prime \prime} \\
\mathrm{E}^{\circ} 43^{\circ} 37.36^{\prime \prime}\end{array}$ & Crackmeter & 0.000 & 0.000 & $0.0 \mathrm{~mm}$ \\
\hline 19.06 .16 & -do- & -do- & 0.000 & 0.000 & $0.0 \mathrm{~mm}$ \\
\hline 26.06 .16 & $\begin{array}{l}\text { N234ㄴ'38.13" } \\
\text { E92 }^{\circ} 43^{\prime} 37.36^{\prime \prime}\end{array}$ & Crackmeter & 0.000 & 0.000 & $8.0 \mathrm{~mm}$ \\
\hline 03.07 .16 & - do- & - do- & 0.000 & 0.000 & $3.2 \mathrm{~mm}$ \\
\hline 10.07.16 & $\begin{array}{l}\text { N234ㄴ'38.13" } \\
\text { E92 }^{\circ} 43^{\prime} 37.36^{\prime \prime}\end{array}$ & Crackmeter & & ERROR & $18.5 \mathrm{~mm}$ \\
\hline 17.07 .16 & -do- & -do- & 0.000 & 0.000 & $5.6 \mathrm{~mm}$ \\
\hline 24.07.16 & $\begin{array}{l}\text { N234ㄴ'38.13" } \\
\text { E92 }^{\circ} 43^{\prime} 37.36^{\prime \prime}\end{array}$ & Crackmeter & 0.000 & 0.000 & $1.1 \mathrm{~mm}$ \\
\hline 31.07 .16 & -do- & - do- & 0.000 & 0.000 & $34.8 \mathrm{~mm}$ \\
\hline 07.08 .16 & $\begin{array}{l}\text { N234ㄴ'38.13" } \\
\text { E92 }^{\circ} 43^{\prime} 37.36^{\prime \prime}\end{array}$ & Crackmeter & 0.000 & 0.000 & $0.0 \mathrm{~mm}$ \\
\hline 14.08 .16 & -do- & - do- & 0.000 & 0.004 & $95.1 \mathrm{~mm}$ \\
\hline
\end{tabular}

taking direction measurements, while slope angles and discontinuity dips were measure with Silva compass. Slope heights and area were measured or estimated using measuring tape and ranging poles. ${ }^{11}$

-13 Photographs of the study area, instrument and measurement were regularly captured by digital camera. Documenting the current stability of a landslide by photography is useful for comparison with any additional slope movement. ${ }^{11}$

2) Hydrogeological monitoring: Automatic rain gauge for continuous recording of rainfall. ${ }^{14-16}$
3) Surface deformation monitoring: The transverse cracks were measure by means of Crackmeters SIS 102 and SIS 100 (Figure 2). This will be installed with anchor pins positioned. The rate of movement will be measured by installing tape extensometers SIS 400 (Figure 3). The connection will be between landslide area and stable location adjacent to the landslide. This instrument will install for continuous measuring of landslide movement. ${ }^{13,16-18}$ The movement measurement time interval is about $24 \mathrm{hrs}( \pm 30$ minutes), i.e. 3:00 P.M. 


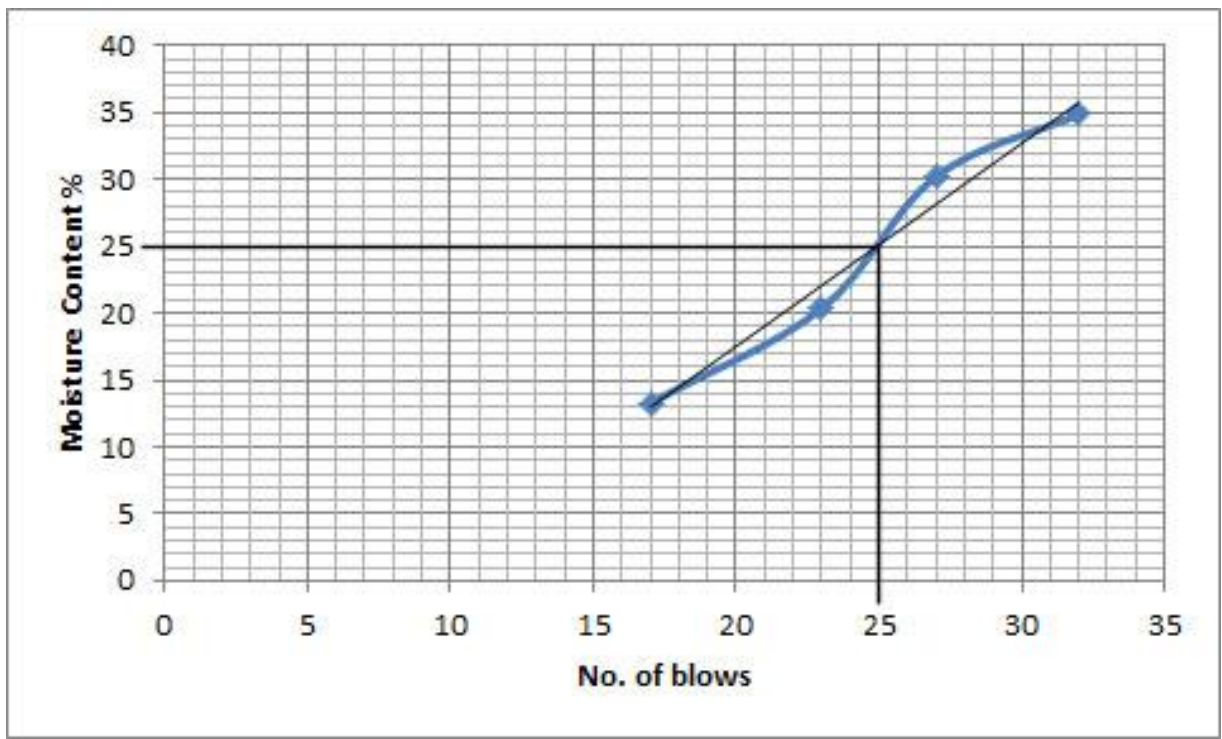

Figure 5 | Liquid limit graph.

\section{Results and Discussions}

Geologically, the study area belongs to Middle Bhuban Formation, and the main rock types are sandstone, siltstone and thin bed of shale. The general slope amount is $50^{\circ}$ due east. Sandstonesiltstone/shale intercalations, jointed vertically exposed along Bangla Lui. A number of cracks developed at the crown portion affecting a number of houses.

The author warns the nearby houses about the possible failure in 2010 after field work along Bangla Lui, studying Ramhlun Vengthar landslide. ${ }^{19}$ The photographic investigation was done in this particular area given in the following Figure 4.

Geology \& Mineral Resources Department, Government of Mizoram, had done bore hole drilling up to $6 \mathrm{~m}$ depth at the selected four sites. They observed that no static level could be recorded due to complete loss of water and, core recovery percent low due to encountered highly fracture sandstone bed and soft friable shale. The project pre-plan of piezometer monitoring is not possible from this observation.

The observation values of liquid limit and plastic limit are given in Table 1. From Figure 5, the liquid limit (LL) value observed is 25 , and plastic limit $(\mathrm{PL})$ is 20.4. The plasticity index is 5.4 and is classified as 'slightly plastic'22,23 and, can be classed as 'semisolid' from consistency index, i.e. 1.031. ${ }^{23}$

The CBR value of $2.5 \mathrm{~mm}$ penetration value ranges from $5.07 \%$ to $6.95 \%$, and $5.56 \%$ to $7.28 \%$ in $5.0 \mathrm{~mm}$ value. The bulk density ranges from 1.79 to 2.08 , dry density from 1.620 to 1.748 , and the MDD ranges between 1.726 to 1.750 and OMC value observed is $15.7 \%$ to $18.6 \%$ (Table 2).
The observed CBR value is less than 10, thus, not suggested for pavement and may cause pavement deterioration. OMC values within standard, but the moisture content observed values are above standard. The MDD values are too low, the soil is not compact but loose and thus susceptible to erosion. $3,10,24$

The observed rate of movement was relatively increased when rainfalls increasing (Table 3 ).

\section{Conclusion}

The geotechnical studies and monitoring of Ramhlun Sports Complex observed that the area is not suitable and unsafe for settlement, construction of road, and not recommended linking road/ pavement. The following are suggested:

$\oplus$ To construct suitable drainage system above the crown, i.e. along the state PWD road of Market-Ramhlun Sports Complex-Ramhlun Vengthar, and Ramhlun Sports Complex link road.

$\oplus$ Settlement and other human activities should be strictly prohibited in the rupture surface.

$\oplus$ Planning of link road in the rupture surface should discontinue due to weak nature of soil strength (CBR value $<10)$.

$\oplus$ Planting of deep-rooted plants may act as resisting forces.

$\oplus$ Deep borehole drilling up to proper bedding, and further detail soil and rock geotechnical studies are suggested. 


\section{Acknowledgement}

The author thanks to UGC for funding investigation and monitoring against project no. F. 5 - 45/2013-14/MRP/NERO.

\section{References}

1. Laldinpuia, Kumar S., Singh T.N. (2014). $11^{\text {th }}$ May, 2013 Laipuitlang rockslide, Aizawl, Mizoram, North- East India. In: Landslide Science for a Safer Geoenvironment, Volume 3: Targeted Landslides, K. Sassa, P. Canuti and Y. Yin (Eds), Springer International Publishing Switzerland, pp. 401-405.

2. GSI-NER (2013). Proceedings of Regional Workshop on Landslide Disaster Management, 2223 November 2013, Shillong, Meghalaya.

3. BIS (1985). IS: 2720 (Part 5)- 1985 Indian Standard Methods of Test for Soils, Part V Determination of liquid and plastic limit, UDC 624-131.532-3, p. 20.

4. Ahmed M.Y., Nury A.H., Islam F., Alam M.J.B. (2012). Evaluation of geotechnical properties and structural strength enhancing road pavement failure along Sylhet-Sunamganj highway, Journal of Soil Science and Environmental Management, 3(5), 110-117.

5. Saklecha P.P., Kedar R.S., Saklecha P.K. (2013). Correlation of CBR with mechanical properties of foundation soil. Proceedings of Indian Geotechnical Conference, 22-24 December 2013, Roorkee, p. 8.

6. Bhatt S., Jain P.K. (2014). Prediction of California Bearing Ratio of soils using artificial neural network. American International Journal of Research in Science, Technology, Engineering \& Mathematics, 156-161.

7. BIS (1988). IS: 2720 (Part 16)- 1987 Indian Standard methods of test for soil, Part 16 laboratory determination of CBR (Second Revision), UDC 624 -131.37: 624-131.524, p.15.

8. Obiefuna G.I, David S.E. (2010). Geological and Geotechnical assessment of selected gully sites in Jada area NE Nigeria. Journal of Environmental Sciences and Resource Management, 2, 22-54.

9. Obiefuna G.I., Adamu J. (2012). Geological and Geotechnical assessment of selected gully sites in Wuro Bayare area NE Nigeria. Journal of Environmental and Earth Sciences, 4(3), 282-302.

10. BIS (1994). IS: 2720 (Part 8)- 1983 Indian Standard methods of test for soils Part 8 determination of water content- dry density relation using heavy compaction (Second Revision), UDC 624131.431.3.624-131.431.5, p. 19.
11. Zaruba, Q., Mencl, V. (1982). Landslide and Their Control. Development in Geotechnical Engineering, 31, 157-167.

12. Duncan J.M. \& Wright S.G. (2005). Soil Strength and Slope Stability. John Wiley \& Sons, New Jersy, p. 280.

13. Wieczorek G.F. \& Snyder J.B. (2009): Monitoring slope movements. In: Geological Monitoring, R. Young \& L. Norby (eds), Colorado, Geological Society of America, doi: 10.1130/2009.monitoring (11), pp. 245-271.

14. Kumar A., Sanoujam M. (2007). Landslide studies along the national highway (NH 39) in Manipur. Natural Hazards, 40, 603-614.

15. Millis S.W., Ho A.N.L., Chan E.K.K., Lau K.W.K., Sun H.W. (2008). Instrumentation and real time monitoring of slope movement in Hong Kong. In: The $12^{\text {th }}$ International Conference of International Association for Computer Methods and Advances in Geomechanics (IACMAG), 1-6 October 2008, Goa, pp. 4563-4576.

16. Sarkar S., Ghost A., Kanungo D.P., Ahmad Z. (2013). Slope Stability Assessment and monitoring of a vulnerable site on Rishikesh- Uttarkashi Highway, India. In: Landslide Science and Practice, 2, 'Early Warning, Instrumentation and Monitoring', Margottini C., Canuti P., \& Sassa K. (eds.), Springer-Verlag, London, pp. 67-72.

17. Mehrotra G.S., Pandey Y., Dharmaraju R., Parkash S. (1996). Instrumentation and monitoring of Matli landslide area in Garhwal Himalaya- A case study. In: Proceedings International Conference on Disasters and Mitigation, A.R. Santhakumar (ed.), Madras, India, 19-22 January 1996, pp. A5-16 to A5-21.

18. Kane W.F., Beck T.J. (1999). Advances in slope instrumentation: TDR and remote data acquisition systems. In: Field Measurements in Geomechanics, $5^{\text {th }}$ International Symposium on Field Measurements in Geomechanics, Singapore, pp. 101-105.

19. Savvaidis, P.D. (2003). Existing Landslide monitoring systems and techniques. In: From Stars to Earth and Culture, Greece, pp. 242-258.

20. Laldinpuia, Kumar S., Singh T.N. (2011). Geotechnical studies of landslides at Ramhlun Vengthar, Aizawl, Mizoram. Memoirs Geological Society of India, 77, 251-258.

21. Anon. (1979). Classification of rocks and soils for engineering geological mapping Part 1: Rock and soil materials. Bulletin of International Association of Engineering Geology, 19, 355-371.

22. Coduto, D. P. (1999). Geotechnical Engineering: 
Principles and Practices, Prentice Hall: New Jersey, pp. 125-155.

23. BS 5930, $1999+$ A2 (2010). Code of practice for site investigations. British Standards Institution.

24. Islam, M.T. (2011). Evaluation of existing SylhetSherpur Highway by dynamic cone penetrometer and computer based AASHTHO software. Journal of Scientific Research, 3(2), 13-20. 